\title{
Abiotic Stress Resistance Analysis of Lilium pumilum Overexpressing the LpMT2 Gene
}

\author{
Ling Wang ${ }^{1}$, Lijuan Fan ${ }^{1}$, Jingjing Zhao ${ }^{1}$, Chang $\mathrm{Xu}^{2} \&$ Shumei Jin ${ }^{2}$ \\ ${ }^{1}$ The College of Landscape Architecture, Northeast Forestry University, Harbin, China \\ ${ }^{2}$ Key Laboratory of Saline-Alkali Vegetation Ecology Restoration in Oil Field (SAVER), Northeast Forestry \\ University, Harbin, China \\ Correspondence: Shumei Jin, Key Laboratory of Saline-alkali Vegetation Ecology Restoration in Oil Field \\ (SAVER), Northeast Forestry University, Harbin 150040, China. Tel: 86-188-4677-8856. E-mail: \\ jinshumei1972@163.com
}

Received: August 16, 2019

Accepted: September 18, 2019

Online Published: November 15, 2019

doi:10.5539/jas.v11n18p76

URL: https://doi.org/10.5539/jas.v11n18p76

The research is financed by the National Natural Science Foundation of China (No.31670344) and the Fundamental Research Funds for the Central Universities (No.2572019DF08) and Nature Scientific Foundation of Heilongiiang Province (LH2019C011).

\begin{abstract}
Plant metallothioneins (MT) are cysteine-rich proteins present in plants that can improve a plant's salt tolerance. Therefore, a greater understanding of the MT gene in lily (Lilium pumilum), Liliaceae, is an important factor in the development and cultivation of improved salt-tolerant varieties and enriching plant resources for saline soils. A type 2 MT gene (GenBank access number: MH319787, designated as LpMT2) was isolated from L. pumilum leaves. The response mechanism to stress was then investigated, which provided the basis for molecular breeding of L. pumilum for stress tolerance. The LpMT2 gene amino acid sequence is highly homologous to that of type 2 MT protein. Quantitative real-time PCR (qPCR) determined that different plant tissues expressed the LpMT2 gene differently and these expressions were dependent on the specific stress. Transgenic plants with LpMT2 gene exhibited significantly increased resistance to salt and oxidative stress compared with untransgenic plants. The LpMT2 transgenic plants had better growth, greater chlorophyll and proline content, less malondialdehyde (MDA) content and cell membrane permeability, greater superoxide dismutase (SOD) activity, less $\mathrm{Na}^{+}$content, greater $\mathrm{K}^{+}$ content and $\mathrm{Na}^{+}$efflux, and less $\mathrm{K}^{+}$efflux. These results determined that the transformed LpMT2 gene in $L$. pumilium plays an important role in enhancing the plant's salt tolerance and antioxidant capacity.
\end{abstract}

Keywords: Lilium pumilum, lily, oxidant stress, metallothionein, salinity, salt tolerance

\section{Introduction}

\subsection{Northeast China Salinity and Lily (Lilium pumilum)}

Northeast China is one of the most severe saline areas in China and one of the three largest saline soils in the world with an area of $3.84 \mathrm{~km}^{2}$ (Yao et al., 2006), accounting for 3.1\% of the total area of the northeast China region (Y. H. Wang \& S. X. Wang, 1994). Only a few salt tolerant plants can survive in this saline area (Jin et al., 2017). $L$. pumilum can grow well in saline soils, but there is limited research on its salt tolerant genes. The Lilium genus, in the family Liliaceae, was established by Linnaeus in 1753 (Takhtajian, 1986), and there are about 115 species identified worldwide (Fu, 2002). L. pumilum is a perennial herb of Lilium and distributed widely in north China. $L$. pumilum research mainly focuses on plant resources (Wu et al., 2006), hybrid breeding (Yang, 2016), the flowering biological characteristics (Fukai \& Goi, 2001), tissue culture (Chen et al., 2013), and reproduction (Chojnowski, 1996). It is also reported that Lilium has resistance to drought and salt stress (Yue, 2012). However, research on the salt tolerance and cloning salt-tolerant genes in Lilium is limited. In Phase \#1 of this research the objective was to screen a salt-tolerant Metallothionein (MT) gene from L. pumilum by qPCR under salt stress and investigate the gene function. 


\subsection{Metallothioneins}

Metallothioneins (MTs) are low molecular weight proteins which are rich in cysteine and exists extensively in organisms (Leszczyszyn et al., 2003). Plant MT was first discovered in soybean (Glycine max) roots (Quan et al., 2006). MTs have many functions, including scavenging reactive oxygen species (ROS) (Akashi et al., 2004), reducing heavy metal ion toxicity (Ferraz et al., 2002), participating in metal ion transport (Fujimoto et al., 2013), remediating contaminated environments (Chen \& Tang, 2013), stabilizing a plant's internal environment (Chang $\&$ Zhu, 2002), and participating in gene regulation (Robinson et al., 1993). MT gene molecular structures, physiological functions and evolutionary relationship were analyzed using the bioinformatics methods for four mushrooms (Qiang et al., 2012).

The MT gene is also related to a plant's resistance to salt and oxidative stress. Transgenic rice plants overexpressing OsMTla demonstrated an enhanced tolerance to drought (Zhao et al., 2009). The OsMTle-P transgenic tobacco plants improved the salt stress tolerance compared to the untransgenic tobacco plants (Kumar et al., 2012). The transgenic Arabidopsis plants overexpressing cgMT1 from beefwood (Casuarina glauca) reduced the accumulation of $\mathrm{H}_{2} \mathrm{O}_{2}$ (Obertello et al., 2007). Transgenic tobacco (Nicotiana tabacum) plants overexpressing GhMT3a showed increased tolerance against abiotic stresses (salt, drought, and low-temperature stresses) compared to wild-type plants (Xue et al., 2009).

In addition, plant MT2 can directly eliminate reactive oxygen species (ROS), such as $\mathrm{O}_{2}{ }^{-}$and $\mathrm{H}_{2} \mathrm{O}_{2}$ (Hassinen et al., 2011). MT protein is thought to be involved in oxidative stress protection (Ahmad et al., 2016). MTs have been found to be responsible for oxidative stress and ROS scavenging (Naoki et al., 2006; Zhang et al., 2019). Salt stress induced ROS generation and ROS scavenging plays an important role in plant stress resistance. We hypothesized that the MT gene molecular pathway improved plant tolerance by inhibiting ROS production and reducing oxidative damage to plant cells.

MT gene expression can be induced in plants, and the impact of metal ions on the MT gene expression in plants is most often studied. Understanding the impact of the MT gene in Lilium pumilum (L. pumilum) will make a significance impact in the development of excellent salt-tolerant varieties and enriching salt-tolerant plant resources. In Phase \#2 of this research the objective was to clone a type 2 MT gene from the L. pumilum leaf under salt stress and determine if the gene will improve the plant's salt tolerance.

\section{Methods and Materials}

\subsection{Phase \#1: Cloning of Full-Length LpMT2 and the Analysis of Relative Expression}

The complete transcription fragment was cloned from cDNA of $L$. pumilum by using sequence-specific primers. The sequence contains an open reading frame of $234 \mathrm{bp}$ and encodes 77 amino acids. The result of BLAST search showed that amino acid sequence of LpMT2 had the highest homology of amino acid sequence with DcMT2 in Dendrobium catenatum (GenBank accession number: XP_020679854.1, similar degree 69\%), the next were AcMT2 in Actinidia chinensis var. chinensis (GenBank number: PSR98280.1, similar degree 67\%), PeMT2 in Phalaenopsis equestris (GenBank number: XP_020571140.1, similar degree 65\%), PtMT2 in Populus trichocarpa (GenBank number: XP 002299873.1, similar degree 64\%); GmMT2 in Glycine max (GenBank number: NP_001235506.1, similar degree 61\%), AtMT2a in Arabidopsis thaliana (GenBank number: P25860.2, similar degree 55\%), (Figure 1). Therefore, this protein was designated as LpMT2.

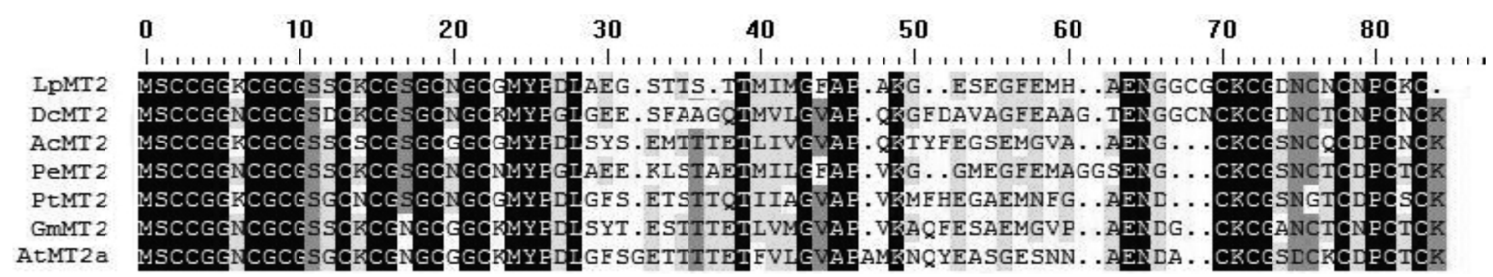

Figure 1. Comparison of the LpMT2 amino acid sequences with homologs from other species

GenBank accession numbers of the aligned sequences are as follows: Dendrobium catenatum DcMT2 (XP_020679854.1), Actinidia chinensis var. chinensis AcMT2 (PSR98280.1), Phalaenopsis equestris PeMT2 (XP_020571140.1), Populus trichocarpa PtMT2 (XP_002299873.1), Glycine max GmMT2 (NP_001235506.1), Arabidopsis thaliana AtMT2a (P25860.2). 


\subsection{Phase \#2: Cloning of Full-Length LpMT2 from L. pumilum}

L. pumilum plants were grown on MS basal medium (Murashige \& Skoog, 1962) in an illuminated incubator at $25^{\circ} \mathrm{C}$ under 2000 Lux irradiation with a $16 \mathrm{~h} \mathrm{light} / 8 \mathrm{~h}$ dark photoperiod. The total ribonucleic acid (RNA) was extracted from 8-week old leaves by RNeasy Plant Mini Kit (Qiagen, Hilden, Germany). First-strand cDNA was synthesized by reverse transcribing $500 \mathrm{ng}$ of total RNA with PrimeScript ${ }^{\mathrm{TM}}$ RT reagent Kit (TaKaRa Bio, Japan).

A transcript fragment was amplified by PCR from the cDNA with the forward primer (5'-ATGTCTTGCTGTGGTGGAAA-3') and reverse primer (5'-TTAGCACTTGCATGGGTTG-3') based on the transcriptome contract sequencing results of L. pumilum. Primers were designed using Primer Premier 5.0 software (Premier Biosoft, Canada). The PCR product was ligated into plasmid pMD18-T vector (Takara Bio, Japan) and sequenced. The sequences were identified using DNAMAN 6.0 software (Lynnon Biosoft, USA). The new gene was designated as LpMT2.

\subsection{The qPCR Analyses of LpMT2 Expression in Different Organs of L. pumulum and Under Different Stress}

RNAs were extracted from the roots (three years old), bulbs (three years old), young leaves (eight week old), mature leaves (three years old), flowers (three years old) and seeds (harvested from three-year old plants) of $L$. pumulum using RNeasy Plant Mini Kit. First-strand cDNA was synthesized by reverse transcribing 500 ng of total RNA with using PrimeScriptTM RT reagent Kit. The primers for qPCR were the same as primers for gene cloning primers. Subsequent qPCR analyses were conducted using SYBR green (TaKaRa Bio, Japan). Each amplification in a 96-well plate was performed in a $20 \mu \mathrm{L}$ final volume containing $2.0 \mu \mathrm{L}$ of $2 \times$ diluted cDNA template; $0.5 \mu \mathrm{L}$ of each specific primer pair at $10 \mu \mathrm{M} ; 10 \mu \mathrm{L}$ of $2 \times$ SYBR Premix Ex Taq and $8.0 \mu \mathrm{L}$ of distilled deionized $\mathrm{H}_{2} \mathrm{O}(\mathrm{dd}$ $\mathrm{H}_{2} \mathrm{O}$ ). The expression level of the lily Actin (Gene Bank Accession Number: JX826390) gene was used as a reference. All analyses were conducted under the following conditions: denaturation for $10 \mathrm{~min}$ at $95{ }^{\circ} \mathrm{C}, 40$ cycles of $30 \mathrm{~s}$ at $95{ }^{\circ} \mathrm{C}, 30 \mathrm{~s}$ at $55^{\circ} \mathrm{C}$ and $72{ }^{\circ} \mathrm{C}$ at 1 min, using an IQ5 real-time PCR instrument (Bio-Rad, Hercules, CA, USA). Fluorescent detection was performed and the results of qPCR were analyzed by MxPro software (Agilent, USA).

Eight-week old untransgenic L. pumilum seedlings were transferred to fresh MS medium at $25^{\circ} \mathrm{C}$ under 2000 Lux irradiation with a $16 \mathrm{~h} \mathrm{light} / 8 \mathrm{~h}$ dark photoperiod, supplemented with $250 \mathrm{mM} \mathrm{NaCl}, 20 \mathrm{mM} \mathrm{NaHCO}$ and $11 \mathrm{mM}$ $\mathrm{H}_{2} \mathrm{O}_{2}$. The leaves were harvested after $0,6,12,24,36$, and $48 \mathrm{~h}$. The LpMT2 gene expression level in L. pumilum seedlings under different stresses were analyzed by qRT-PCR.

\subsection{Construction of Plant Expression Vectors and L. pumilum Transformation}

The coding region of the LpMT2 gene was amplified from pMD18-T-LpMT2 with the BamHI forward primer 5'-GGATCCATGTCTTGCTGTGGTGGAAA-3' and XhoI reverse primer 5'-C'TCGAGTTAGCACTTGCATGG GTTG-3'. The PCR product was ligated into plasmid pMD18-T vector. The plasmids were digested with BamHI and $\mathrm{XhoI}$ and then ligated into the BamHI and XhoI sites of pBI121 binary vector plasmids (We altered the vector). The plasmid DNA of pBI121-LpMT2 was transformed into the L. pumilum bulbs by Agrobacterium tumefaciens (strain EHA105 Takara, Tokyo, Japan) mediated transformation (Ishida et al., 1996; Zhao et al., 2002). The bulbs were germinated on MS $+0.5 \mathrm{mg} \cdot \mathrm{mL}^{-1} \mathrm{BA}+0.05 \mathrm{mg} \cdot \mathrm{mL}^{-1} \mathrm{NAA}$ plates containing $50 \mathrm{mg} \cdot \mathrm{L}^{-1}$ kanamycin (kana) to select kana-resistance plants, and the kana-resistance plants were transferred to fresh MS medium at $25{ }^{\circ} \mathrm{C}$ under $2000 \mathrm{Lux}$ irradiation with a $16 \mathrm{~h}$ light $/ 8 \mathrm{~h}$ dark photoperiod. Finally transgenic plants were identified using Northern blot (Jin et al., 2017). RNAs were extracted from eight-week old transgenic L. pumilum seedlings.

\subsection{Stress Tolerance Analysis of the L. pumilum}

Eight-week old L. pumilum untransgenic and transgenic seedlings at the same growth stage were selected for fresh MS medium + $200 \mathrm{mM}, 250 \mathrm{mM}, 300 \mathrm{mM} \mathrm{NaCl}, 9 \mathrm{mM}, 11 \mathrm{mM}, 13 \mathrm{mM} \mathrm{H}_{2} \mathrm{O}_{2}, 20 \mathrm{mM}, 50 \mathrm{mM}, 80 \mathrm{mM} \mathrm{NaHCO}_{3}$ stress treatment at $25^{\circ} \mathrm{C}$ under $2000 \mathrm{Lux}$ irradiation with a $16 \mathrm{~h} \mathrm{light} / 8 \mathrm{~h}$ dark photoperiod for $48 \mathrm{~h}$ to observe the extent of leaf injury. The leaf centers were determined by SPAD-502 Plus Chlorophyll Meter Model (Konica Minolta, Japan). The relative value of chlorophyll content in each leaf was measured. The free proline (Pro) content was determined by the ninhydrin method (Ma et al., 2007). Malondialdehyde (MDA) content was determined by the thiobarbituric acid method (Hodges et al., 1999). The degree of cell membrane damage was determined by conductance (Liu et al., 2008). Superoxide dismutase (SOD) was determined by its ability to inhibit the photochemical reduction of nitro blue tetrazolium (NBT) (Giannopolitis \& Ries, 1977).

Eight-week old untransgenic and transgenic L. pumilum seedlings were treated without (control) or with each of following solutions: $20 \mathrm{mM} \mathrm{NaHCO}$ and $250 \mathrm{mM} \mathrm{NaCl}$, respectively for $48 \mathrm{~h}^{-\mathrm{Na}^{+}}$and $\mathrm{K}^{+}$ion content of leaves were measured by an atomic absorption spectrophotometer (AA800, Perkin Elmer, USA) (Barragan et al., 2012). Net flux of the roots' $\mathrm{K}^{+}$and $\mathrm{Na}^{+}$were measured using Noninvasive Micro-test Technology (Zhao et al., 2017). 
The data were analyzed using a one-way analysis of variance using SPSS 20.0 (IBM, USA) with Duncan's one-way analysis of variance. The figures were drawn using SigmaPlot 12.5 (Systat Software Inc., USA).

\section{Results}

\subsection{LpMT2 Gene Expression in L. pumilum}

LpMT2 gene had the greatest expression in flowers, followed by young leaves, seeds, mature leaves, bulbs and roots (Figure 2a). It was confirmed that the expression of LpMT2 gene was greater in the aboveground plant parts (flowers, leaves, and seeds). Under $250 \mathrm{mM} \mathrm{NaCl}$ stress, the LpMT2 expression reached the greatest level at $36 \mathrm{~h}$, about 18 times greater than the gene expression in the control (Figure 2b). The LpMT2 expression for $250 \mathrm{mM}$ $\mathrm{NaCl}$ tended to stabilize from 12 to $24 \mathrm{~h}$ and then dramatically increased at $36 \mathrm{~h}$. When exposed to $20 \mathrm{mM}$ $\mathrm{NaHCO}_{3}$ stress, the gene expression was relatively low (less than 2) until $48 \mathrm{~h}$, when it was about 14 times greater than the control (Figure 2c). The LpMT2 expression due to $11 \mathrm{mM} \mathrm{H}_{2} \mathrm{O}_{2}$ stress increased gradually with treatment time, reaching the greatest level at $48 \mathrm{~h}$, which was about 4.5 times greater than the control (Figure 2d).
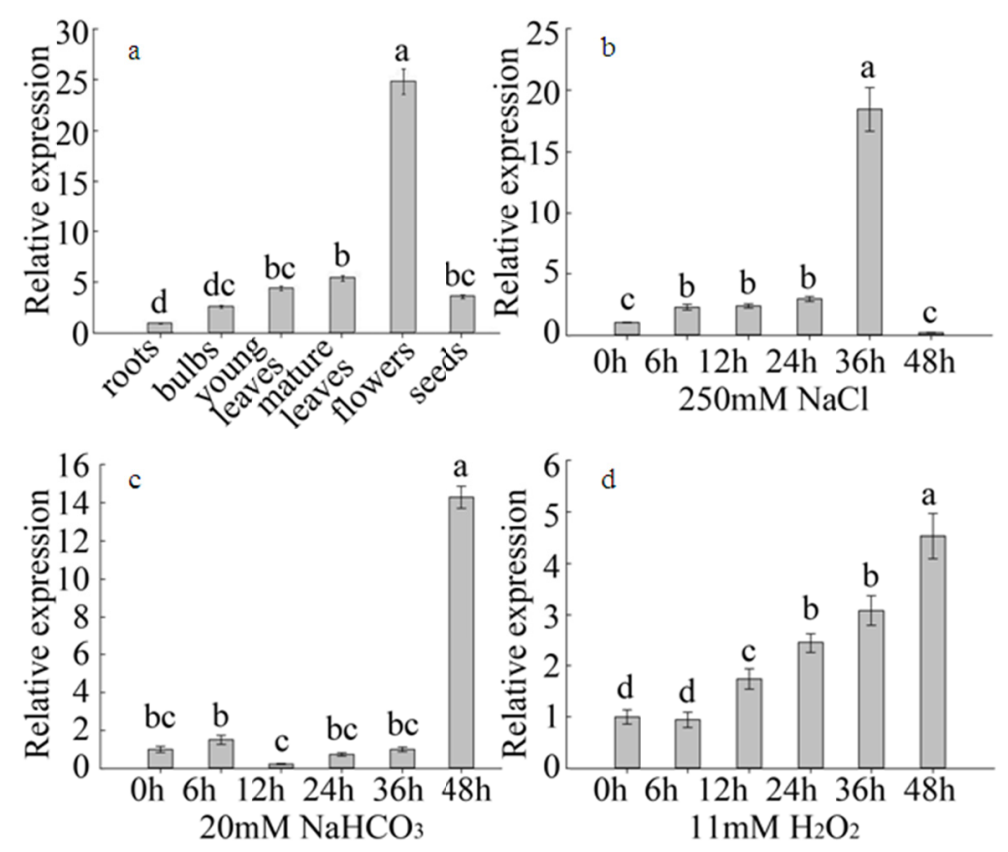

Figure 2. Relative expression of LpMT2. (a) Relative expression of LpMT2 in different organs of L. pumilum. (b) Relative expression of LpMT2 gene under $\mathrm{NaCl}$ treatment. (c) Relative expression of LpMT2 gene under $\mathrm{NaHCO}_{3}$ treatment. (d) Relative expression of LpMT2 gene under $\mathrm{H}_{2} \mathrm{O}_{2}$ treatment

\subsection{Identification of Transgenic L. pumilum Lines Using Northern Blot}

Three transgenic $L$. pumilum lines (\#1,\#2 and \#3) were selected for Northern blot analysis. The overexpression of the LpMT2 gene in transgenic L. pumilum was due to the CaMV35S promoter. The transgenic lines had a greater LpMT2 gene expression than the untransgenic plants due to the stronger hybridization signals (Figure 3). 


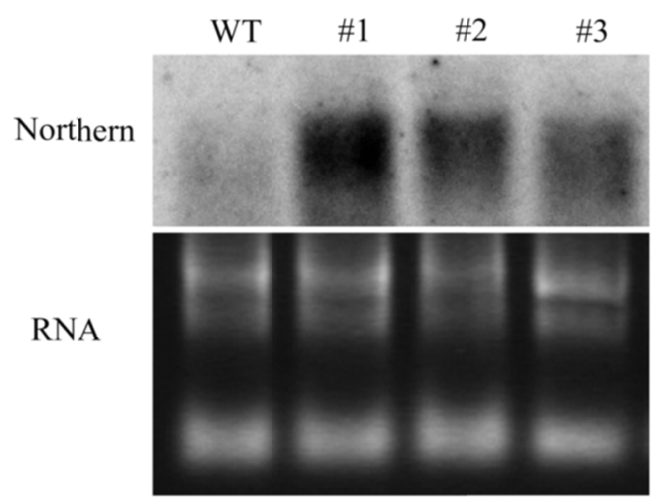

Figure 3. Northern blot analysis of LpMT2 gene expression in transgenic plants

Untransgenic plant genotype was negative control (CK), and transgenic plants were \#1, \#2, \#3. Total RNA (lower

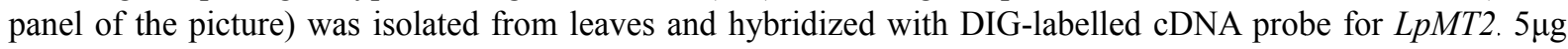
RNA was used into each lane. Full-length blot and gel are presented in Supplementary Figure 1.

\subsection{Analysis of Plant Phenotype, Physiological Index, Icon Content, and Flux Under Various Stress Treatments}

After $48 \mathrm{~h}$, under different stress concentrations, the leaves showed injury signs at low concentrations with increasing injury as the stress levels increased. Phenotype observation determined that the transgenic lines were more stress tolerant than the untransgenic plants (Figure 4). As the stress concentrations increased, the plant chlorophyll content gradually decreased. The chlorophyll content of the untransgenic plants was generally less than the transgenic plants under the same stress conditions. These results indicate that the LpMT2 gene enhanced the plant's photosynthesis to varying levels (Figure 5a). The proline content in the plants increased significantly after stress treatments and the increase was greater for the transgenic plants. It was determined that transgenic plants could produce more proline under stress, and, therefore, had a greater resistance to stress (Figure 5b). With the increase of stress concentration, the content of MDA increased first and then decreased for both the transgenic and untransgenic plants (Figure 5c). When under stress, the increase MDA content was greater for the untransgenic plants than the transgenic plants. The MDA content in untransgenic plants was $140 \%, 48 \%$, and $26 \%$ greater than the transgenic plants under $250 \mathrm{mM} \mathrm{NaCl}, 80 \mathrm{mM} \mathrm{NaHCO}_{3}$, and $11 \mathrm{mM} \mathrm{H}_{2} \mathrm{O}_{2}$, respectively. 

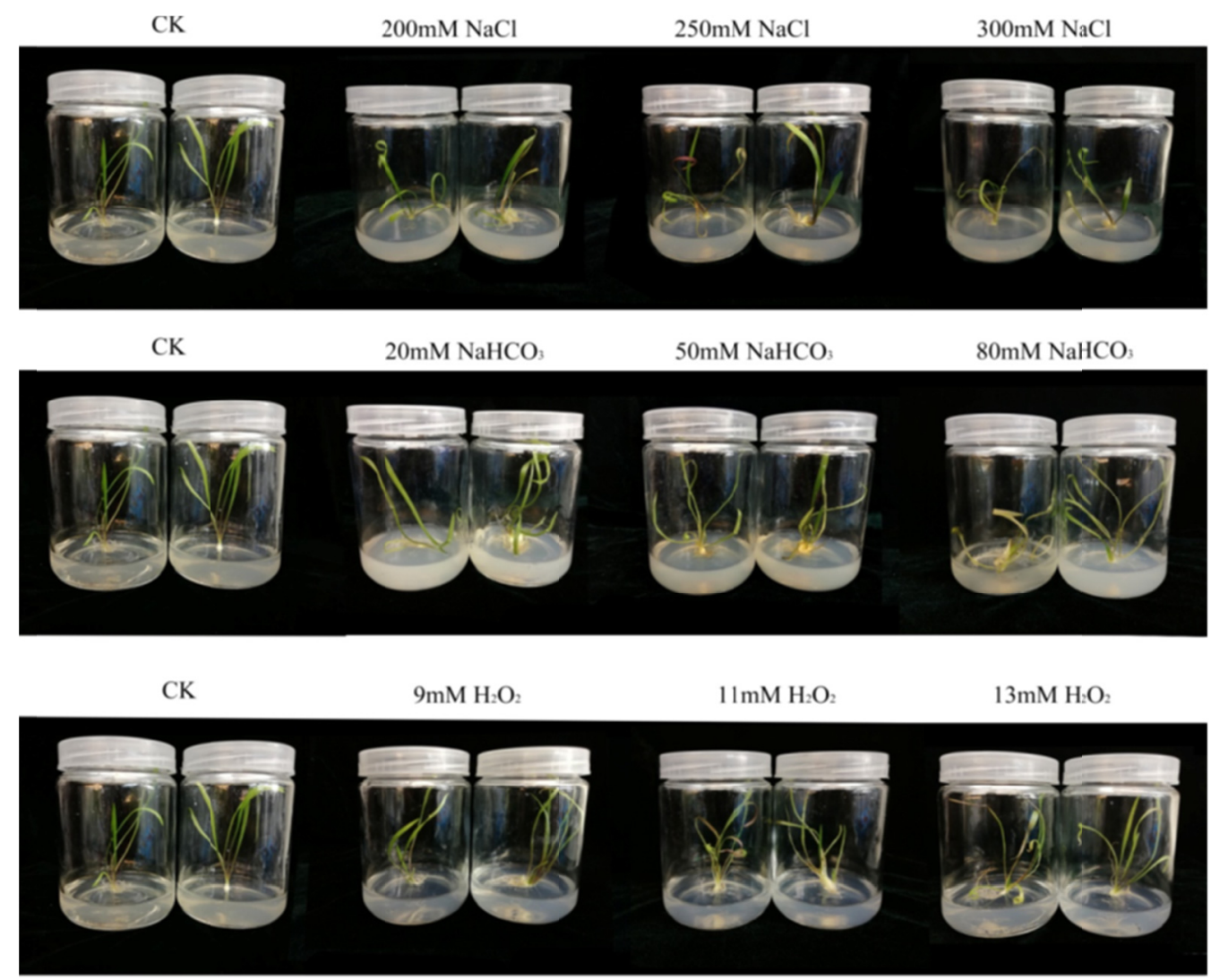

Figure 4. Phenotype of untransgenic and transgenic plants under different stress

Eight-week old L. pumilum untransgenic and transgenic seedlings at the same growth stage were selected for fresh MS medium + $200 \mathrm{mM}, 250 \mathrm{mM}, 300 \mathrm{mM} \mathrm{NaCl}, 9 \mathrm{mM}, 11 \mathrm{mM}, 13 \mathrm{mM} \mathrm{H}_{2} \mathrm{O}_{2}, 20 \mathrm{mM}, 50 \mathrm{mM}, 80 \mathrm{mM} \mathrm{NaHCO}$ stress treatment at $25^{\circ} \mathrm{C}$ under $2000 \mathrm{Lux}$ irradiation with a $16 \mathrm{~h}$ light $/ 8 \mathrm{~h}$ dark photoperiod for $48 \mathrm{~h}$. The plant on the left is the untransgenic plant and the transgenic one is on the right.

The change in electrical conductivity (EC) may reflect the degree of plasma membrane damage and the strength of the plant's resistance to stress. The change in EC of transgenic plants was less than the untransgenic plants when under stress. The plant's EC increased as the stress concentration increased, indicating that the degree of cell membrane damage is more serious in untransgenic plants (Figure 5d).

The SOD activity for untransgenic plants was significantly less than that the transgenic lines under stress. The SOD activity first increased and then decreased with increasing stress (Figure 5e). Under $250 \mathrm{mM} \mathrm{NaCl}, 50 \mathrm{mM}$ $\mathrm{NaHCO}_{3}$, and $11 \mathrm{mM} \mathrm{H}_{2} \mathrm{O}_{2}$ stress treatments, the SOD activity in transgenic plants was $60 \%, 10 \%$ and $60 \%$ greater than the untransgenic plants, respectively. 


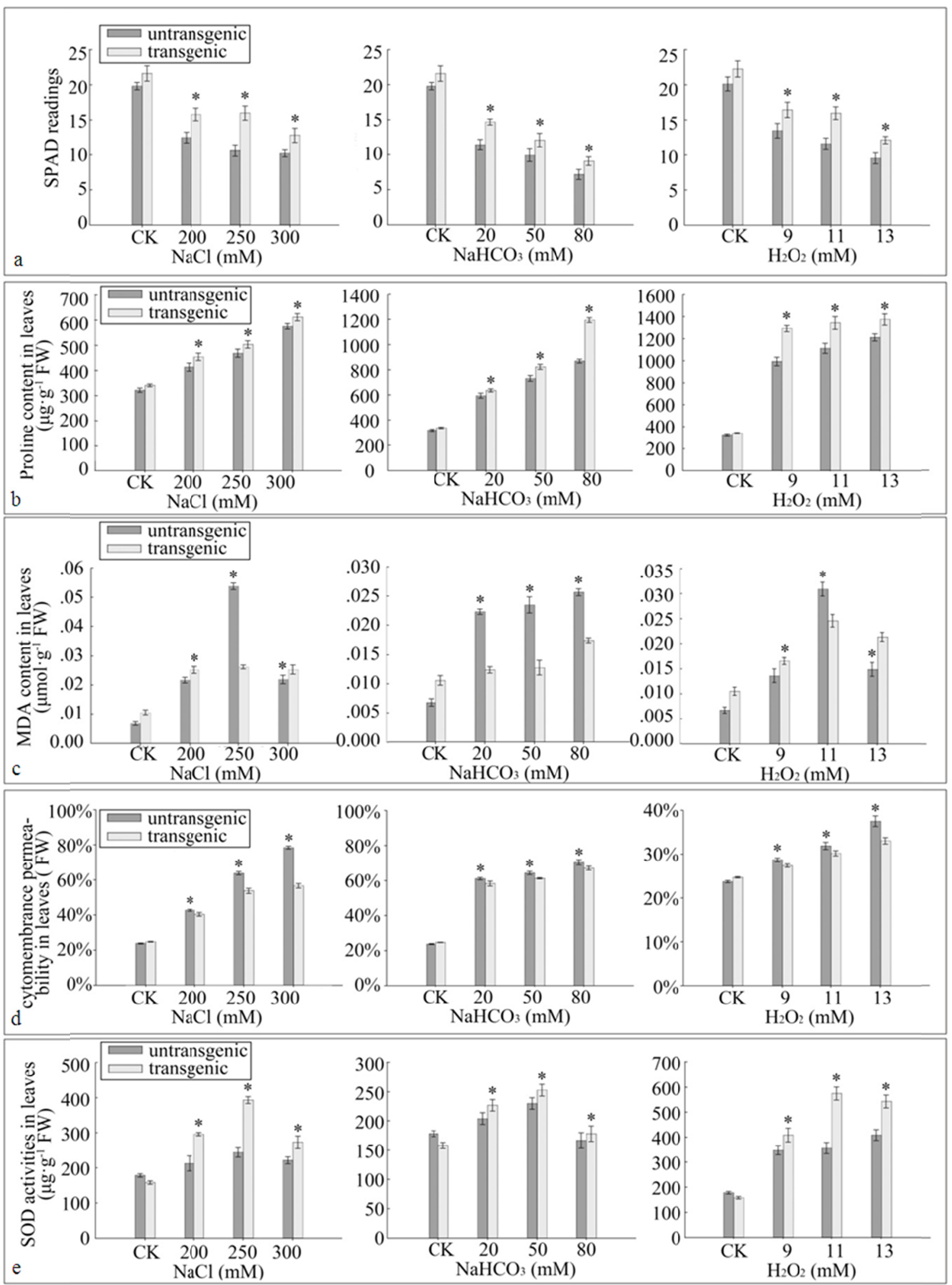

Figure 5. Physiological index of untransgenic and transgenic plants under stress conditions. (a) SPAD readings (SPAD is a unit of relative value of chlorophyll content measured using SPAD-502 Plus Chlorophyll Meter Model).

(b) Proline content. (c) MDA content. (d) Cytomembrane permeability. (e) SOD activity. Asterisks indicate significant differences between untransgenic and transgenic plants $(\mathrm{P}<0.05)$ 
Compared with the control, the $\mathrm{Na}^{+}$content and salt concentration significantly increased after saline stress. The increasing trend of transgenic plants was less than that the untransgenic plants (Figure 6a). The $\mathrm{K}^{+}$content of the transgenic plants decreased significantly and was less than the untransgenic plants (Figure 6b). NMT flux data revealed that $\mathrm{Na}^{+}$efflux in the roots' apical regions significantly increased in all plants under saline conditions. Under $250 \mathrm{mM} \mathrm{NaCl}$ and $20 \mathrm{mM} \mathrm{NaHCO}_{3}$ treatments, the $\mathrm{Na}^{+}$efflux rate in transgenic plants was $15 \%$ and $20 \%$ greater than the untransgenic plants (Figure $6 \mathrm{c}$ ). $\mathrm{NaCl}$ and $\mathrm{NaHCO}_{3}$ treatment changed the $\mathrm{K}^{+}$flux from influx to efflux. The $\mathrm{K}^{+}$efflux rate in untransgenic plants was $46 \%$ and $26 \%$ greater than the untransgenic plants (Figure $6 d)$.

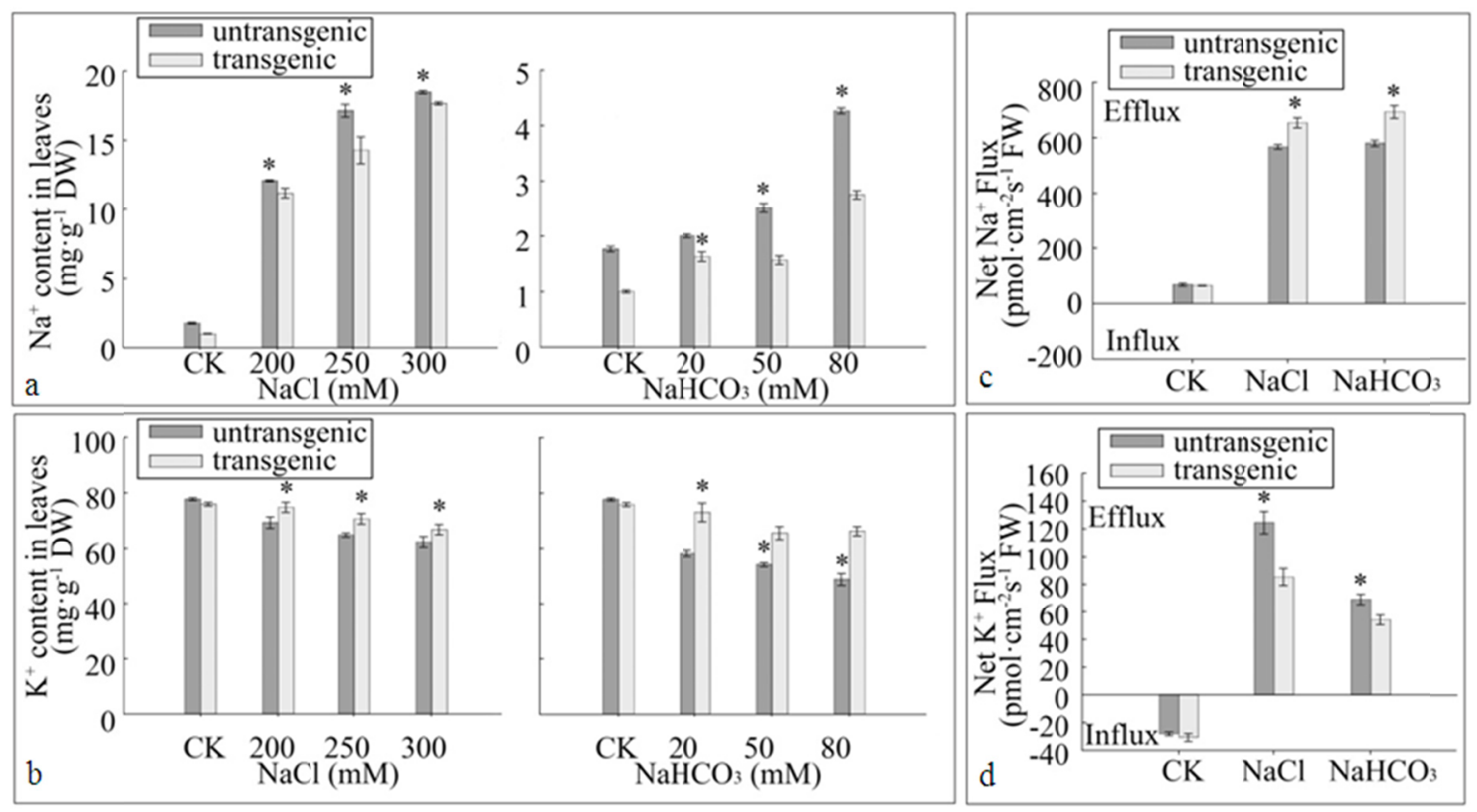

Figure 6. $\mathrm{Na}^{+}$and $\mathrm{K}^{+}$content and Fluxes of leaves in untransgenic and transgenic plants under $\mathrm{NaCl}$ and $\mathrm{NaHCO}_{3}$ stress. (a) $\mathrm{Na}^{+}$content. (b) $\mathrm{K}^{+}$content. (c) Net $\mathrm{Na}^{+}$Fluxes. (d) Net $\mathrm{K}^{+}$Fluxes. Positive values represent efflux. Asterisks indicate significant differences between untransgenic and transgenic plants $(\mathrm{P}<0.05)$

\section{Discussion}

Depending on the position and arrangement of the cysteine residues, type 2 MTs sequence has three characteristics, the first and second Cys, which appear in the form of Cys-Cys contiguous, and most of them exist in the 3rd and 4th position of the N-terminal, a highly conserved sequence MSCCGGNCGCG exists in the N-terminal, and three Cys-X-Cys elements are arranged in the structure domain of C-terminal (Cobbett \& Goldsbrough, 2002). The cysteine arrangement in the LpMT2 gene has the characteristics of type 2 MTs, and LpMT2 belongs to the type 2 metallothionein family.

Different MTs often exhibit different expression patterns. The specific expression of MhMT2 gene in Malus hupehensis was analyzed by Wang et al. (2012). The results showed that the MhMT2 gene expression was the greatest in leaves, followed by roots, and least in stems. Our results showed that LpMT2 transcripts were preferentially expressed in flowers, followed by mature leaves, young leaves and seeds, but also expressed to a lesser extent in the underground plant tissues.

One of the basic characteristics of MT genes is inducibility (Jin et al., 2006). MT genes are expressed in response to salinity, ROS, heavy metals, environmental stress, hormones, damage, and virus infection in some plants (Nishiuchi et al., 2007). The MT stress resistance is primarily focused on metal resistance. Although there are studies related to salt stress, there are few related to oxidative stress. Liu et al. (2011) cloned the metallothionein gene of Limonium sinense and analyzed its expression pattern under high salt exposure. When treated with ABA, $\mathrm{H}_{2} \mathrm{O}_{2}$, mechanical damage, and $\mathrm{NaCl}$, the MhMT2 gene expression was up-regulated in Malus hupehensis leaves, among which $\mathrm{H}_{2} \mathrm{O}_{2}$ treatment was the most obvious. In our research, L. pumilum was treated with different salts $\left(\mathrm{NaCl}\right.$ and $\left.\mathrm{NaHCO}_{3}\right)$ and oxidative $\left(\mathrm{H}_{2} \mathrm{O}_{2}\right)$ stressors and treatment exposer times. LpMT2 gene expression in 
leaves increased gradually with the increase time exposed to $\mathrm{NaHCO}_{3}$ and $\mathrm{H}_{2} \mathrm{O}_{2}$ stress. While under the $\mathrm{NaCl}$ stress, the LpMT2 gene expression in leaves increased and then decreased. These results indicate that the induction of LpMT2 gene expression was related to the salt and oxidative stresses.

Under certain stress levels, a plant's cytochrome system will be destroyed, leading to a decrease in chlorophyll content ( $\mathrm{Li}$ et al., 2016). The chlorophyll content of untransgenic plants' leaves had a greater decreasing trend than the transgenic $L$. pumilum plants under salt stress. This is an indication that LpMT2 has a significant impact on plant chlorophyll content. Proline, as an effective plant osmotic regulator, can scavenge reactive oxygen species (ROS), reduce lipid peroxidation, and prevent toxic amino acids accumulation (Li et al., 2011). When plants are subjected to environmental stress, the accumulation of proline increases significantly, which can enhance plant resistance to stress (Zhang et al., 2006). When under stress, the proline content was greater in the transgenic plants compared to the untransgenic plants. Various adverse environments often first influence the cell membrane (Xu et al., 2007). Relative conductivity reflects the cell membrane integrity, while MDA is an indicator of membrane lipid peroxidation, which together reflects the degree of cellular damage (Verslues et al., 2006). The increase in MDA content in the early stage of stress indicates that the membrane lipid peroxidation occurred. As the treatment concentration increased, the MDA content decreased, which may be due to the excessive lipid peroxidation consumption due to respiration. The cell membrane destruction in transgenic plants was less than the untransgenic plants. SOD plays a very important role in protecting cells from oxidative damage (Giannopolitis \& Ries, 1977). SOD activity decreased more in transgenic plants than that in the untransgenic plants as a result of stress. This is an indication that the LpMT2 gene transfer reduced membrane peroxidation and protected the plants. When comparing the physiological indexes between the transgenic and untransgenic L.pumilum, the transgenic resistant plants were significantly greater than the untransgenic plants.

Salt stress destroys the plant's intracellular nutritional balance, primarily due to the excessive $\mathrm{Na}^{+}$accumulation, which causes ion poisoning and other elemental deficits (Flowers et al., 2010). $\mathrm{K}^{+}$is an essential nutrient for plant growth, but because of the antagonism between $\mathrm{Na}^{+}$and $\mathrm{K}^{+}$, it is necessary to maintain a high $\mathrm{K}^{+}$content in order to improve the salt tolerance of plants (Adams et al., 1992). Under salt stress, due to the accumulation of $\mathrm{Na}^{+}, \mathrm{K}^{+}$ uptake is inhibited and there is a decrease in plant $\mathrm{K}^{+}$. The $\mathrm{Na}^{+}$concentration in the transgenic plants was less than the untransgetic plants, while the $\mathrm{K}^{+}$concentration was greater under saline stress. These results demonstrate that transgenic plants can control $\mathrm{Na}^{+}$uptake, maintain $\mathrm{K}^{+}$content in leaves, and ensure normal growth under stress.

Salt stress weakens $\mathrm{Na}^{+}$absorption and transport, and accelerates the $\mathrm{Na}^{+}$poisoning (Guo et al., 2005). The transgenic plant $\mathrm{Na}^{+}$efflux rate under salt stress was significantly greater than the untransgenic plants, while $\mathrm{K}^{+}$ efflux rate was the opposite. This is an indication that the transgenic plants can adapt to a saline environment by increasing the $\mathrm{Na}^{+}$efflux rate and reducing the $\mathrm{K}^{+}$efflux rate, therefore, the transgenic plants had greater stress resistance.

The biological MT protein has been studied for over 60 years, but its exact function is still unclear. In recent years the function of the MT gene and protein relationship to abiotic stress has been predominantly understood, but the molecular mechanism of how the MT gene regulates a plant response to stress is not clear, therefore, the investigation of plant MT continues to be important.

The over expression of LpMT2 gene improves the salt tolerance of L. pumilum, but the impact of high salt stress on plant growth and development is very complex. Halophytes can grow in a saline environment as the result of a combination of various salt-tolerant mechanisms. In addition, the function of MT in abiotic stress has been primarily understood in recent years, but the molecular mechanism of how the MT regulates a plant's response to stress is not yet clear. Further research on the physiological metabolism and cell structure of transgenic L. pumilum will be helpful to reveal the role of MT accumulation in plants and its relationship to salt tolerance in plants.

\section{Conclusions}

In this research we isolated a LpMT2 gene from L. pumilum, proved that the gene expression was different in different plant organs or under different stresses, and characterized its function in L. pumilum. This study indicates that the LpMT2 gene enhanced the transgenic plants' tolerance to salts $\left(\mathrm{NaCl}\right.$ and $\left.\mathrm{NaHCO}_{3}\right)$ and oxidative $\left(\mathrm{H}_{2} \mathrm{O}_{2}\right)$ stress. The following conclusions can be drawn from this research: 1) A 234bp long MT2 gene encoding 77 amino acids was cloned by PCR using cDNA of L. pumilum leaves as a template. QRT-PCR results showed that the LpMT2 gene has the greatest expression in flowers and the expression was significantly induced under salt and oxidative stress. 2) The plant expression vector pBI121-LpMT2 was constructed and transferred into the bulbs of $L$. pumilum by Agrobacterium-mediated successfully. 3) The untransgenic and transgenic L. pumilum were treated with different concentrations of $\mathrm{NaCl}, \mathrm{NaHCO}_{3}$, and $\mathrm{H}_{2} \mathrm{O}_{2}$ for $48 \mathrm{~h}$. Compared with untransgenic plants, transgenic 
plants had better growth, greater chlorophyll and proline content, less MDA content, smaller cell membrane permeability, greater SOD activity, less $\mathrm{Na}^{+}$content, greater $\mathrm{K}^{+}$content, greater $\mathrm{Na}^{+}$efflux and less $\mathrm{K}^{+}$efflux.

\section{References}

Adams, P., Thomas, J. C., Vernon, D. M., Bohnert, H. J., \& Jensen, R. G. (1992). Distinct cellular and organismic responses to salt stress. Plant Cell Physiol, 33, 1215-1223.

Akashi, K., Nishimura, N., Ishida, Y., \& Yokota, A. (2004). Potent hydroxyl radical-scavenging activity of drought-induced type-2 metallothionein in wild watermelon. Biochem Biophys Res Commun, 323, $72-78$. https://doi.org/10.1016/j.bbrc.2004.08.056

Barragan, V., Leidi, E. O., Andres, Z., Rubio, L., De Luca, A., Fernandez, J. A., ... Pardo, J. M. (2012). Ion exchangers NHX1 and NHX2 mediate active potassium uptake into vacuoles to regulate cell turgor and stomatal function in Arabidopsis. Plant Cell, 24, 1127-1142. https://doi.org/10.1105/tpc.111.095273

Chang, T. J., \& Zhu, Z. (2002). Study advances of plant metallothionein expression characteristics and functions of plant MT gene. Biotechnol Bul, 3, 6-10.

Chen, L. J., Yin, X. J., Li, J. L., Zhong, M., Ma, H., Li, H. G., ... Tao, C. G. (2013). Induction of Lilium pumilun bulb and establishment of genetic transformation's tissue culture system. Southwest China J of Agr Sci, 26, 718-722.

Chen, M., \& Tang, Y. L. (2013). Advances in transgenic plants for phytoremediation. Biotechnol Bul, 6, 7-11.

Chojnowski, M. (2012). Germination of Lilium pumilum seeds. Acta Hort, 325, 235-238. https://doi.org/10.17660/ ActaHortic.1992.325.28

Cobbett, C., \& Goldsbrough, P. (2002). Phytochelatins and metallothioneins: roles in heavy metal detoxification and homeostasis. Annu Rev Plant Biol, 53, 159-182. https://doi.org/10.1146/annurev.arplant.53.100301. 13515412

Ferraz, P., Fidalgo, F., Almeida, A., \& Teixeira, J. (2002). Phytostabilization of nickel by the zinc and cadmium hyperaccumulator Solanum nigrum L. Are metallothioneins involved? Plant Physiol and Biochem, 57, 254-260. https://doi.org/10.1016/j.plaphy.2012.05.025

Flowers, T. J., Gaur, P. M., Gowda, C. L., Krishnamurthy, L., Samineni, S., Siddique, K. H., ... Colmer, T. D. (2010). Salt sensitivity in chickpea. Plant Cell Environ, 33(4), 490-509. https://doi.org/10.1111/j.1365-3040. 2009.02051.x

Fu, L. G. (2002). Higher plants of China Qingdao. Publishing House, 13, 118-133.

Fujimoto, S., Itsumura, N., Tsuji, T., Anan, Y., Tsuji, N., Ogra, Y., ... Kambe, T. (2013). Cooperative functions of $\mathrm{ZnT} 1$, metallothionein and ZnT4 in the cytoplasm are required for full activation of TNAP in the early secretory pathway. PLoS One, 8(10). https://doi.org/10.1371/journal.pone.0077445

Fukai, S., \& Goi, M. (2001). Floral initiation and development in Lilium longiflorum Thunb. Tech Bull of Faculty of Agr-Kagawa Univ, 53, 31-34.

Giannopolitis, C. N., \& Ries, S. K. (1977). Superoxide dismutases: I. Occurrence in higher plants. Plant Physiol, 59, 309-314. https://doi.org/10.1104/pp.59.2.309

Guo, P., Zhang, W. J., \& Bao, Y. J. (2005). Influence of salt stress on the ion flow velocity of the Na+ and K+ ion in alfalfa root. J of Dalian Nationalities Univ, 17, 439-444.

Hassinen, V. H., Tervahauta, A. I., Schat, H., \& Karenlampi, S. O. (2011). Plant metallothioneins-Metal chelators with ROS scavenging activity? Plant Biol, 13, 225-232. https://doi.org/10.1111/j.1438-8677.2010.00398.x

Hodges, D. M., DeLong, J. M., Forney, C. F., \& Prange, R. K. (1999). Improving the thiobarbituric acid-reactive-substances assay for estimating lipid peroxidation in plant tissues containing anthocyanin and other interfering compounds. Planta, 207, 604-611. https://doi.org/10.1007/s004250050524

Ishida, Y., Saito, H., Ohta, S., Hiei, Y., Komari, T., \& Kumashiro, T. (1996). High efficiency transformation of maize (Zea mays L.) mediated by Agrobacterium tumefaciens. Nature Biotechnol, 14, 745-750. https://doi.org/10.1038/nbt0696-745

Jin, S. M., Cheng, Y. X., Guan, Q. J., Liu, D. L., Takano, T., \& Liu, S. K. (2006). A metallothionein-like protein of rice (rgMT) functions in E-coli and its gene expression is induced by abiotic stresses. Biotechnol Lett, 28, 1749-1753. https://doi.org/10.1007/s10529-006-9152-1 
Jin, S., Xu, C., Li, G., Sun, D., Li, Y., Wang, X., \& Liu, S. (2017). Functional characterization of a type 2 metallothionein gene, SsMT2, from alkaline-tolerant Suaeda salsa. Sci Rep, 7, 17914. https://doi.org/ $10.1038 / \mathrm{s} 41598-017-18263-4$

Joshi, R., Ashwani, P., \& Sneh, L. S.-P. (2016). Plant Metallothioneins: Classification, Distribution, Function, and Regulation. Plant Metal Interaction: Emerging Remediation Techniques (Chap. 9, pp. 239-261). Elsevier. https://doi.org/10.1016/B978-0-12-803158-2.00009-6

Kumar, G., Kushwaha, H. R., Panjabi-Sabharwal, V., Kumari, S., Joshi, R., Karan, R., ... Pareek, A. (2012). Clustered metallothionein genes are co-regulated in rice and ectopic expression of OsMT1e-P confers multiple abiotic stress tolerance in tobacco via ROS scavenging. BMC Plant Biology, 12, 107-107. https://doi.org/10.1186/1471-2229-12-107

Leszczyszyn, O. I., Imam, H. T., \& Blindauer, C. A. (2003). Diversity and distribution of plant metallothioneins: A review of structure, properties and functions. Metallomics, 5, 1146-1169. https://doi.org/10.1039/c3mt00072a

Li, R., Yang, L. P., \& Liu, X. N. (2011). Comparative study on heat resistance of Lily hybrids and their parents. Scientia Agr Sinica, 44, 1201-1209.

Li, Y. N., Yuan, S. X., Xu, L. F., Yang, P. P., Feng, Y. Y., Younes, P. H., \& Ming, J. (2016). The physiological response of Lily to $\mathrm{NaHCO}_{3}$ stress. Acta Hort Sinica, 43, 1126-1140.

Liu, X. L., Hua, X. J., Guo, J., Qi, D. M., Wang, L. J., Liu, Z. P., ... Liu, G. S. (2008). Enhanced tolerance to drought stress in transgenic tobacco plants overexpressing VTE1 for increased tocopherol production from Arabidopsis thaliana. Biotechnol Lett, 30, 1275-1280. https://doi.org/10.1007/s10529-008-9672-y

Ma, J. Y., Zhou, B. C., Xia, D. S., Zhang, H. W., \& Jiang, X. L. (2007). Relationships between environmental factors and chlorophyll, proline accumulation in desert plant Reaumuria soongorica. Acta Botanica Boreali-Occidentalia Sinica, 27, 769-775.

Murashige, T., \& Skoog, F. (1962). A revised medium for rapid growth and Bio assays with Tobacco tissue cultures. Physiol Plant, 15, 473-497. https://doi.org/10.1111/j.1399-3054.1962.tb08052.x

Naoki, F., Masuo, K., Satoshi, U., Minoru, H., Masufumi, T., Shinya, S., ... Bulletin, P. (2006). Involvement of oxidative stress in the synthesis of metallothionein induced by mitochondrial inhibitors. Biol Pharm Bull, 29, 2016-20. https://doi.org/10.1248/bpb.29.2016

Nishiuchi, S., Liu, S. K., \& Takano, T. (2007). Isolation and characterization of a metallothionein-1 protein in Chloris virgata Swartz that enhances stress tolerances to oxidative, salinity and carbonate stress in Saccharomyces cerevisiae. Biotechnol Lett, 29, 1301-1305. https://doi.org/10.1007/s10529-007-9396-4

Obertello, M., Wall, L., Laplaze, L., Nicole, M., Auguy, F., Gherbi, H., ... Franche, C. (2007). Functional analysis of the metallothionein gene cgMT1 isolated from the actinorhizal tree Casuarina glauca. Molecular Plant-Microbe Interactions, 20, 1231. https://doi.org/10.1094/MPMI-20-10-1231

Qiang, C., Zhou, B., Yang, X., Wei, F., Lu, Z., Wang, S., ... Wang, S. (2012). Bioinformatics analysis of metallothionein gene from Agaricus bisporus, Ganoderma lucidum, Taiwanofungus camphorates and Paxillus involutus. Agric Sci, 3, 900-904. https://doi.org/10.4236/as.2012.37109

Quan, X. Q., Zhang, H. T., Shan, L., \& Bi, Y. P. (2006). Advances in plant metallothionein and its heavy metal detoxification mechanisms. Hereditas, 28, 375-382.

Robinson, N. J., Tommey, A. M., Kuske, C., \& Jackson, P. J. (1993). Plant metallothioneins. Biochem J, 295, 1-10. https://doi.org/10.1042/bj2950001

Takhtajian, A. (1986). Floristic Regions of the World Berkeley. Univ of California Press.

Verslues, P. E., Agarwal, M., Katiyar-Agarwal, S., Zhu, J., \& Zhu, J. K. (2006). Methods and concepts in quantifying resistance to drought, salt and freezing, abiotic stresses that affect plant water status. Plant $J, 45$, 523-539. https://doi.org/10.1111/j.1365-313X.2005.02593.x

Wang, S. C., Liang, D., \& Ma, F. W. (2012). Cloning and expression analysis of metallothionein gene (Mh MT2) in Malus hupehensis. Scientia Agr Sinica, 45(14), 2904-2912.

Wang, Y. H., \& Wang, S. X. (1994). Saline-alkali disaster and the treatment in Northeast China. Water Resources \& Hydropower of Northeast China, 10, 27-30.

Wu, Z. H., Shi, J. S., Chi, J., Xi, M. L., Hu, F. R., \& Jiang, F. X. (2006). Research advances on resources and breeding of ornamental Lily. J of Nanjing for Univ Natural Sci Edition, 30, 113-118. 
Xu, S., He, X. Y., Chen, W., \& Li, J. L. (2007). Ecophysiological responses of Festuca arundinacea to high temperature stress. Chinese J of Appl Ecol, 18, 2219-2226.

Xue, T., Li, X. W., Wu, C., Yang, G., \& Zheng, C. (2009). Cotton metallothionein GhMT3a, a reactive oxygen species scavenger, increased tolerance against abiotic stress in transgenic tobacco and yeast. $J$ of Experimental Botany, 60, 339-349. https://doi.org/10.1093/jxb/ern291

Yang, L. P. (2016). Research progress of Lily hybridization and breeding technologies. Northern Hort, 15.

Yang, W. R., \& Fei, Q. X. (2008). Advances in investigation, introduction and domestication of wild germplasm resources of Lilium in China. J of Anhui Agri Sci, 36, 8065-8067.

Yao, R. J., Yang, J. S., \& Liu, G. M. (2006). Charaeteristics and agro-biological management of saline-alkalized land in Northeast China. Soils, 38, 256-262.

Yue, L. (2012). Study progress on resistance of Lilium. Hort \& Seed, 6, 119-122.

Zhang, M., Liu, S., Takano, T., \& Zhang, X. J. P. (2019). The interaction between AtMT2b and AtVDAC3 affects the mitochondrial membrane potential and reactive oxygen species generation under $\mathrm{NaCl}$ stress in Arabidopsis. Planta, 249, 417-429. https://doi.org/10.1007/s00425-018-3010-y

Zhang, W., Yang, H. Q., Jie, Y. L., Li, Q., Zhao, H. Z., \& Zhang, X. R. (2006). Effects of abscisic acid, salicylic acid and oxalic acid on induction of proline accumulation in apple leaves. Acta Hort Sinica, 33, 1175-1178.

Zhao, Y., Wu, Y., Ye, L., Ling, H. Q., \& Chu, C. (2009). OsMT1a, a type 1 metallothionein, plays the pivotal role in zinc homeostasis and drought tolerance in rice. Plant Mol Biol, 70, 219-229. https://doi.org/10.1007/ s11103-009-9466-1

Zhao, Z. X., Zhang, G. Q., Zhou, S. M., Ren, Y. Q., \& Wang, W. (2017). The improvement of salt tolerance in transgenic tobacco by overexpression of wheat F-box gene TaFBA1. Plant Sci, 259, 71-85. https://doi.org/10.1016/j.plantsci.2017.03.010

Zhao, Z. Y., Gu, W. N., Cai, T. S., Tagliani, L., Hondred, D., Bond, D., ... Pierce, D. (2002). High throughput genetic transformation mediated by Agrobacterium tumefaciens in maize. Mol Breeding, 8, 323-333. https://doi.org/10.1023/A:1015243600325

Zhu, G. H., Zhang, J. J., Chen, J. S., \& Peng, X. X. (2008). Characterization of a rice metallothionein type 3 gene with different expression profiles under various nitrogen forms. Biologia Plantarum, 52, 668-673. https://doi.org/10.1007/s10535-008-0129-x

Zhu, W., Zhao, D. X., Miao, Q., Xue, T. T., Li, X. Z., \& Zheng, C. C. (2009). Arabidopsis thaliana Metallothionein, AtMT2a, mediates ROS balance during oxidative stress. J. Plant Biol., 52, 585. https://doi.org/10.1007/s12374-009-9076-0

\section{Copyrights}

Copyright for this article is retained by the author(s), with first publication rights granted to the journal.

This is an open-access article distributed under the terms and conditions of the Creative Commons Attribution license (http://creativecommons.org/licenses/by/4.0/). 